\title{
Collagen Alpha-5(IV) Chain
}

National Cancer Institute

\section{Source}

National Cancer Institute. Collagen Alpha-5(IV) Chain. NCI Thesaurus. Code C71451.

Collagen alpha-5(IV) chain (1685 aa, $\sim 161 \mathrm{kDa}$ ) is encoded by the human COL4A5 gene.

This protein is involved in the structure of the extracellular matrix. 